In short, we already have a system of damages which adequately compensates both a plaintiff who is permanently injured and one who represents the beneficiaries or the estate of a decedent. The plaintiff whose life expectancy has been shortened is akin to both and should be compensated correspondingly.

\title{
SECTION 5 OF THE CLAYTON ACT-CONSENT DECREES AND THE STATUTE OF LIMITATIONS
}

Section 5 of the Clayton Act $^{1}$ is designed to relieve private claimants of some of the difficulty and expense of proving a violation and resultant damage under the antitrust laws. Litigants can introduce as prima facie evidence in their treble-damage actions a judgment or decree obtained in a successful government antitrust suit against the same defendant. As an added advantage, the private suitor is also allowed to wait for such a judgment since the statute of limitations will not run against his claim during the pendency of a government action. ${ }^{2}$ Until recently, however, this section, and the problems it was likely to engender, lay dormant. Only a small number of treble-damage actions were brought, and few of these contained the proper elements for a test of the ambiguities in the language of Section 5. Now, with treble-damage actions based on government judgments becoming more common ${ }^{3}$-particularly suits based on the motion-picture litigation ${ }^{4}$ - the private litigant may find that a potentially invaluable statute can mislead him.

${ }^{1} 38$ Stat. 731 (1914), 15 U.S.C.A. \$16 (1951).

= The policies of allowing treble-damage actions and of suspending the statute of limitations are both the subject of current debate. In 1951, H.R. 3408 was introduced during the first session of the $82 \mathrm{~d}$ Congress providing for a uniform six-year statute of limitations. The bill was never reported out of committee and in 1953 a similar bill, H.R. 467, was introduced. This too has not been reported. H.R. 4597, providing for compensatory damages and treble damages at the judge's discretion, was also introduced in the Eighty-third Congress and committee hearings were held on it. Hearings before Subcommittee No. 3 of the Committee on the Judiciary on H.R. 4597, 83d Cong. 1st. Sess. (1953). At present the Attorney General's Committee To Study the Antitrust Laws is conducting a study of the whole field of antitrust law with the statute of limitations and treble-damage problems on the agenda.

${ }^{3}$ The following data show the number of private antitrust suits filed in the federal courts during the period 1942-1953: 1942, 70;1943, 40;1944, 50;1945, 27;1946, 68; 1947,$64 ; 1948,78 ; 1949,162 ; 1950,157 ; 1951,209 ; 1952,261 ; 1953,212$. Annual Report of the Director of the Administrative Office of the United States Courts 106 (1953).

- As of May 3, 1951, there were 121 treble-damage suits pending in the federal courts against motion-picture companies for a total alleged treble damage of $\$ 339,555,925$. Hearings before Subcommittee on Study of Monopoly Power of the House Committee on the Judiciary, 82d Cong. 1st. Sess. Ser. No. 1, Pt. 3, 109 (1951). 
Section 5 reads as follows:

That a final judgment or decree hereafter rendered in any criminal prosecution or in any suit or proceeding in equity brought by or on behalf of the United States under the antitrust laws to the effect that a defendant has violated said laws shall be prima facie evidence against such defendant in any suit or proceeding brought by any other party against such defendant under said laws as to all matter respecting which said judgment or decree would be an estoppel between the parties thereto: Provided, This section shall not apply to consent judgments or decrees entered before any testimony has been taken. ... .5

Whenever any suit or proceeding in equity or criminal prosecution is instituted by the United States to prevent, restrain or punish violations of any of the antitrust laws, the running of the statute of limitations in respect of each and every private right of action arising under said laws and based in whole or in part on any matter complained of in said suit or proceeding shall be suspended during the pendency thereof.

Where the government has brought an antitrust action and terminated the proceedings, often temporarily, by consent decree, this section poses troublesome alternatives for the treble-damage suitor seeking its assistance. He may bring his action immediately, assuming the costly burden of proving an antitrust violation, the amount of damage suffered and the causal relationship between the two. Or he may wait, if he is certain the statute of limitations is suspended, in the hope that the government will reopen the action and obtain an admissible judgment. In addition, the litigant must evaluate the probability not only that the government will eventually obtain a judgment but that such judgment will be admissible. In examining both the pendency and the admissibility issues in relation to consent decrees the finality of which is doubtful, this comment will attempt to show that by establishing a relationship between the two issues, the pendency issue may be settled in a manner more consistent with the objectives of Section 5 .

Since the second paragraph of Section 5 suspends the running of the statute of limitations against private claims during the "pendency" of government actions, the meaning the courts have ascribed to pendency and the tests used in applying that meaning in particular cases become important inquiries for the private litigant. Out of the private litigation based on United States v. Paramount Pictures ${ }^{6}$ have come several criteria for determining the period of pendency, most of them related to the words

\footnotetext{
5 The omitted provision pertained to actions pending at the time the act was passed. It was excluded from the code as temporary legislation.

' 334 U.S. 131 (1948). The citation refers to the last full opinion rendered by the Supreme Court. Subsequently, the Court dealt with minor phases of the litigation. 338 U.S. 802 (1949), 339 U.S. 947 (1950). A complete and concise history of the litigation with all citations appears in CCH, The Federal Antitrust Laws 1890-1951, case no. 434 (1952).
} 
"final judgment or decree" at the beginning of Section 5. In Leonia Amusement Corp. v. Loere's Inc., ${ }^{7}$ it was held that government actions should be considered pending "until the entry of a judgment or decree which finally disposes of all the allegations of antitrust violations." In elaborating on that rule the court relied upon several cases which dealt with finality in order to determine the admissibility of a judgment, not to resolve the pendency issue. ${ }^{9}$ In Barnett v. Warner Bros. Pictures Distr. Corp., ${ }^{10}$ some detail was added to the above rule. It was held that suit ends "(1) when final judgment has been entered after trial and appellate proceedings are concluded, or (2) when final judgment is entered by consent of the parties."11 This statement assumes the finality that a proper test should define; the problem remains of determining whether a particular consent decree constitutes "final judgment."

In one sense a consent decree is never final, since the court which rendered it has an inherent equitable power to modify the decree when changed circumstances warrant. This is true whether the decree so provides or not. ${ }^{12}$ In addition, the decree may contain a provision retaining the court's jurisdiction over the cause with either a limited or a general power to construe, enforce or modify the decree. While the above attributes might suggest that a consent decree is little more than a simple contract between the parties, the consent decree has virtually the same legal effect as a contested decree. It bears a near-immunity from direct attack except on grounds that actual consent or jurisdiction is lacking.13 By accepting the decree the defendant waives the right to complain that the enjoined acts are not illegal or that the court had no power to enjoin them. If the court has jurisdiction of the parties and the cause, it has the power to enjoin

'117 F. Supp. 747 (S.D. N.Y., 1953).

${ }^{8} \mathrm{Ibid}$., at 758.

${ }^{\circ}$ Berman v. United States, 302 U.S. 211 (1937); John Simmons Co. v. Grier Bros. Co., 258 U.S. 82 (1922). In Don George, Inc. v. Paramount Pictures, 111 F. Supp. 458 (W.D. La., 1951), it was held that a particular consent decree did not terminate pendency of the government's action while at the same time the decree was admitted in evidence as final. While this case recognized that the finality issue might be answered differently depending upon whether the pendency or the admissibility question were involved, the result reached was inequitable since RKO remained subject to treble-damage suits indefinitely even though private litigants had the admissible judgment they needed to assist their cases.

${ }^{20} 112$ F. Supp. 5 (N.D. Mll., 1953).

${ }^{21}$ Ibid., at 7.

22 "We are not doubtful of the power of a court of equity to modify an injunction in adaptation to changed conditions, though it was entered by consent. . . A continuing decree of injunction directed to events to come is subject always to adaptation as events may shape the need. ... The result is all one whether the decree has been entered after litigation or by consent." United States v. Swift \& Co., 286 U.S. 106, 114 (1932).

${ }^{13}$ Swift \& Co. v. United States, 276 U.S. 311 (1928). Consult The Modification of Antitrust Consent Decrees, 63 Harv. L. Rev. 320 (1949). 
even legal activities as long as consent has been obtained. ${ }^{14}$ Moreover, a consent decree, like a contested decree, invokes the rules of estoppel by judgment in respect to all matters contained therein..$^{15}$

A decree may, however, contain provisions which expressly or impliedly state that it is to be considered only as a temporary termination of the proceedings. For example, the decree entered in 1940 in the Paramount case $^{16}$ has been universally held to have kept the suit pending. ${ }^{17}$ As in most decrees, jurisdiction was retained only for the express purpose of enabling either party to enforce the provisions through appropriate court orders or to seek modification consonant with changed circumstances. Another provision, common to many decrees, was the listing of several contingencies upon which the decree would become inoperative. Finally, it was stated that the decree would remain in force for a trial period of three years, during which the government would refrain from seeking the full relief prayed for in the complaint. It was implied, at least, that the government might prosecute on the entire complaint after the trial period, and the decree would then be inoperative; however, if the case were not reopened the decree would remain effective indefinitely.

The decisive differences between this consent decree and others which have been held effective to terminate suit are not readily discernible. The courts passing on the Paramount decree were apparently impressed with the general implication contained therein that suit might be reopened after three years to obtain additional relief. It is clear, at least, that not all of the allegations in the complaint were disposed of and the decree for that reason would not meet the test of finality mentioned in the Leonia case. On the other hand, it was specified in the provision retaining jurisdiction that either party might petition for modification consonant with changed circumstances whether new and unforeseen or not; no mention was made of a right to reopen the entire case for trial on the original complaint. ${ }^{18}$ It is perhaps important that the court decisions followed the actual reopening of the Paramount case in 1944; under the circumstances it would have been difficult to hold that the earlier consent decree was "final." 19

"Swift \& Co. v. United States, 276 U.S. 311, 331 (1928).

${ }^{15}$ Fifth and Walnut, Inc. v. Loew's Inc., 176 F. 2d 587, 593 (C.A. 2d, 1949).

${ }^{18}$ The decree is set forth in full in 1940-1943 Trade Cases $\{56,072$.

${ }^{17}$ Leonia Amusement Corp. v. Loew's Inc., 117 F. Supp. 747 (S.D. N.Y., 1953) ; Christenson v. Paramount Pictures, 95 F. Supp. 446 (D. Utah, 1950) ; Twentieth Century-Fox Film Corp. v. Brookside Theatre Corp., 194 F. 2d 846 (C.A. 8th, 1952). Cf. United States v. Paramount Pictures, 66 F. Supp. 323, 333 (S.D. N.Y., 1946).

${ }^{18}$ 1940-1943 Trade Cases $₫ 56,072$ at $\$$ XXIII(e).

${ }^{10}$ On August 7, 1944, the government petitioned for modification and defendant answered on the merits. The case was then restored to the trial calendar and finally on June 11, 1946, a judgment of conviction was entered. CCH, The Federal Antitrust Laws 1890-1951, case no. 434 (1952). 
A second consent decree which has been held not to terminate suit was the one entered against RKO Radio Pictures Inc. in 1948. ${ }^{20}$ The paragraph retaining jurisdiction in that decree stated that its purpose was to

enable either party to apply for such orders or directions as may be necessary for the construction, modification or carrying out of the same, for the enforcement of compliance therewith, and for the punishment of violation thereof, or for other and further relief (emphasis added).

While the last clause might appear to open the way for further proceedings based on the initial complaint, the entire paragraph would be subject to the rule of construction that general words following particular words will not include things of a larger class. ${ }^{21}$ Thus, applying the distinction suggested by the cases, a petition for modification of the decree would be allowed while prosecution on the original complaint for full relief would not. Moreover, since the government's complaint was dismissed, disposing of the allegations, the decree clearly met the finality test of the Leonia case. Recently, one court appears to have been swayed by these or similar considerations, holding this same decree to have terminated the action. ${ }^{22}$

The cases seem to reflect a judicial tendency to find that particular decrees do not terminate government actions. This may stem from a fear that private litigants, having waited for a contested government judgment while a consent decree was in force, will find that the statute of limitations has barred their claims. For this reason, the courts are likely to search carefully for any language in a decree allowing further proceedings which might culminate in a final admissible judgment.

This position, that some consent decrees do not operate to cut off pendency, has been severely criticized. ${ }^{23}$ It is argued that defendants may be subjected indefinitely to treble-damage suits since the decree, though subject to modification, may continue in force for many years. This fact, it is claimed, would seriously impair the use of consent decrees in antitrust litigation.

${ }^{20}$ 1948-1949 Trade Cases $\$ 62,335$. Don George, Inc. v. Paramount Pictures, 111 F. Supp. 458 (W.D. La., 1951), held that this decree did not terminate the government's action.

${ }^{21}$ This rule, often labeled ejusdem generis, would appear to confine any subsequent proceedings to those which a court of equity is ordinarily empowered to hear even in the absence of any special provision and would not seem to allow for a reopening of suit on the original complaint. The rule is an aid to interpretation and construction and may be disregarded when the result would mean a plain disregard of actual intent. Gullickson v. Mitchell, 113 Mont. 359, 365, 126 P. 2d 1106, 1110 (1942); Anderson \& Kerr Drilling Co. v. Bruhlmeyer, 134 Tex. 574, 582, 136 S.W. 2d 800, 804 (1940); City of Lexington v. Edgerton, 289 Ky. 815, 818, 159 S.W. 2d 1015, 1017 (1942).

${ }^{2}$ Barnett v. Warner Bros. Pictures Distr. Corp., 112 F. Supp. 5 (N.D. Ill., 1953).

${ }^{23}$ Brown, Venue and Statute of Limitations, Proceedings of the New York State Bar Association, Section on Antitrust Law 56 (1952). 
Touching first upon the contention that private actions will be allowed for an indefinite time, it may be noted that statutes of limitation are not designed to frustrate valid claims for injury. Rather, the object is to bar all claims when memories have failed, documentary evidence is lost and witnesses are no longer available. ${ }^{24}$ With this in mind the argument for reinstating the statute of limitations upon entry of consent decrees should logically extend to both treble-damage suits and the reopening of government proceedings. But if actions may be reopened ten years and more beyond the entry of a consent decree it hardly seems unreasonable to require the preservation of evidence a few years more in anticipation of treble-damage suits. ${ }^{25}$

The claim that consent decrees would fall into disuse unless their effect was to start the statute running again disregards the fact that entry of a consent decree would remain the best and only alternative to a full trial, perhaps resulting in an unfavorable judgment upon which treble-damage suits might rest. Moreover, defendants would be strongly induced to continue under a consent decree, knowing that the government could force a trial of the issues, and private litigants would then descend upon the losing defendants with their claims. ${ }^{26}$

The private litigant's second major concern is the admissibility of a government judgment as prima facie evidence in a subsequent private suit against the same defendant. In Proper v. John Bene Sons, ${ }^{27}$ an early case interpreting

27 Telegraphers v. Ry. Express Agency, 321 U.S. 342 (1944); Preston and Newsom, Limitation of Actions 2 (3d ed., 1953).

${ }^{25}$ Since the antitrust laws contain no statute of limitations the state law applicable to similar actions is controlling. Chattanooga Foundry \& Pipe Works v. City of Atlanta, 203 U.S. 390 (1906). While there is some remaining doubt, it is usually held that the applicable statutes are those which cover compensatory actions and not those relating to recovery of a penalty. Leonia Amusement Corp. v. Loew's Inc., 117 F. Supp. 747 (S.D. N.Y., 1953); City of Atlanta v. Chattanooga Foundry \& Pipeworks Co., 127 Fed. 23 (C.A. 6th, 1903). But cf. Hoskins Coal \& Dock Corp. v. Truax Traer Coal Co., 191 F. 2d 912 (C.A. 7th, 1951). Consult Vold, Are Threefold Damages under the Antitrust Act Penal or Compensatory?, $28 \mathrm{Ky}$. L. J. 117 (1940). The average period of the applicable statues is 4.20 years. For an itemized list of the statutes, consult Hearings before the Subcommittee on Study of Monopoly Power of the House Committee on the Judiciary, 82d Cong. 1st Sess. Ser. No. 1, Pt. 3, at 117 (1951). Consult also Treble Damage Time Limitations: Federalism Rampant, 60 Yale L. J. 553 (1951).

${ }^{20}$ Unless the statute of limitations were tolled during the period when a consent decree is in force, it is conceivable that a defendant, faced with a serious charge, might submit to a consent decree only until the statute had run against all private actions. If the defendant then forced a trial of the issues he would stand to lose the amount of a fine or the right to pursue the illegal activity but would not face the burden of treble-damage suits. It should be noted parenthetically at this point that the Clayton Act does not purport to forbid the filing of private actions while a government suit is pending. It gives the private litigant his choice.

${ }^{27} 295$ Fed. 729 (S.D. N.Y., 1923). A further point of decision was that findings made by the Federal Trade Commission are inadmissible because not arising under the anti- 
Section 5 , the statutory requirements for admissibility were first delineated: (1) the judgment or decree must be final, (2) it must have been rendered in a criminal prosecution or suit in equity, (3) the action must have been instituted under the antitrust laws and (4) it must be to the effect that a defendant has violated those laws. The court failed to mention one other requirement: that the judgment or decree be an estoppel as between the parties; it was implied that any final judgment would invoke the doctrine of res judicata. The apparent shift was harmless, however, since res judicata and estoppel by judgment are substantially identical. ${ }^{28}$

But the statutory provision which is probably of most concern to the treble-damage suitor is the section providing that consent judgments or decrees entered before any testimony is taken are inadmissible. Available statistics indicate that the vast majority of civil antitrust actions brought by the government are terminated by consent decree. ${ }^{29}$ Rarely, then, can the private litigant count on the government to obtain a judgment admissible in treble-damage suits. Moreover, when the Antitrust Division chooses to initiate criminal proceedings the action is more than likely to be terminated on a plea of nolo contendere ${ }^{30}$ which, the courts have held, is also within the consent-judgment exemption..$^{31}$

The exemption proviso would appear to bear the negative implication that consent judgments entered after the taking of testimony are admissible

trust laws nor final until confirmed on appeal to a federal court. Accord: BrunswickBalke-Collender Co. v. American Bowling \& Billiard Corp., 150 F. 2d 69 (C.A. 2d, 1945).

${ }^{2}$ Res judicata appears to have two distinct meanings. One applies to repetitious suits involving the same cause of action to the effect that parties to the suit and their privies are bound "not only as to every matter which was offered and received to sustain or defeat the claim or demand, but as to any other admissible matter which might have been offered for that purpose." Cromwell v. County of Sac, 94 U.S. 351, 352 (1876). The second meaning applies where the second action between the same parties is upon a different cause of action and invokes the rule that only as to "those matters in issue or points controverted, upon the determination of which the finding or verdict was rendered," are the parties barred from further litigation. Ibid., at 353. This second meaning to which the court in the Proper case apparently referred is also labelled estoppel by judgment or collateral estoppel. Commissioner v. Sunnen, 333 U.S. 591 (1948). Consult Rest. Judgments $\$ \$ 47,48,68,69$, 70 (1942); Von Moschzisker, Res Judicata, 38 Yale L. J. 299 (1929); Scott, Collateral Estoppel by Judgment, 56 Harv. L. Rev. 1 (1942).

20 While up-to-date statistics are not presently available, the most recent figures indicate that between 1920 and 1946,169 consent decrees were entered while the total number of government civil actions was 372. Antitrust in Action, Monograph No. 16, Temporary National Economic Committee of the Senate, 76th Cong. 2d Sess. Appendices A-G (1946).

${ }^{30}$ During the period $1920-1946$, 160 nolo contendere pleas were entered out of a total of 314 criminal actions. Tbid.

${ }^{31}$ Twin Ports Oil Co. v. Pure Oil Co., 26 F. Supp. 366 (D. Minn., 1939); Barnsdall Refining Corp. v. Birnamwood Oil Co., 32 F. Supp. 308 (E. D. Wis., 1940). 
in private suits. In Don George Inc. v. Paramount Pictures, ${ }^{32}$ such a decree was admitted in evidence. Strictly speaking, however, the decree did not meet all the statutory requirements for admissibility, for there was no provision in the decree to the effect that the defendant had violated the antitrust laws. The background was as follows: RKO Radio Pictures had defended and lost an antitrust action brought by the government; ${ }^{33}$ on appeal to the Supreme Court, the judgment was affirmed in part, but the entire case was remanded for further proceedings; ${ }^{34}$ RKO then submitted to a consent decree covering all of the government's allegations. The George court admitted this decree in evidence, but only as to those matters upon which the Supreme Court had affirmed. ${ }^{35}$ The decision, as far as it goes, appears correct since the decree contained no express denial of violation, and the Supreme Court ruled that defendant had violated the antitrust laws. Since a number of other courts have also found the RKO decree to be admissible in private litigation, little doubt remains about the admissibility of that particular decree. ${ }^{36}$ Because of the unique circumstances surrounding the entry of the RKO decree, however, it would be unsafe to conclude that the decisions admitting it stand for the proposition that all consent decrees entered after the taking of testimony are admissible in private treble-damage actions.

There appear to be no decisions as yet on the admissibility of consent judgments entered after the taking of testimony which expressly state that a violation is not admitted. While the negative implication of the exemption proviso is that they are admissible, it is equally clear that since such decrees lack any provision to the effect that the defendant has violated the antitrust laws, they do not meet the requirements in the main part of Section 5. To resolve this ambiguity it is necessary to return to a consideration of the purposes behind these two parts of the statute.

The express design of the exemption proviso is to induce prompt capitulation to the government by withdrawing the threat of treble-damage suits

${ }^{22} 111$ F. Supp. 458 (W.D. La., 1951).

${ }^{23}$ U.S. v. Paramount Pictures, 70 F. Supp. 53 (S.D. N.Y., 1946).

3 U.S. v. Paramount Pictures, 334 U.S. 131 (1948).

${ }^{35}$ Neither the decision of the Supreme Court nor the judgment rendered earlier by the district court was admissible. Fifth and Walnut v. Loew's Inc., 176 F. 2d 587 (C.A. $2 d, 1949$ ), held that the district-court judgment was not final and that the Supreme Court had rendered a "decision," not a "final judgment"-a point of contrast said to have been made in Cohen v. Beneficial Industrial Loan Corp., 337 U.S. 541 (1949). The court added that the practicalities of the situation likewise precluded admissibility because the status of the Paramount case at that time would have been difficult to explain to a jury-an argument which might well apply to the consent decree in the George case.

${ }^{38}$ Homewood Theatre, Inc. v. Loew's Inc., 110 F. Supp. 398 (D. Minn., 1952); Deluxe Theatre Corp. v. Balaban \& Katz Corp., 95 F. Supp. 983 (N.D. Il., 1951) ; Twentieth Century-Fox Film Corp. v. Brookside Theatre Corp., 194 F. 2d 846 (C.A. 8th, 1952); Fanchon \& Marco v. Paramount Pictures, 100 F. Supp. 84 (S.D. Calif., 1951). 
based on favorable government judgments in cases where the defendant consents at an early stage of trial. ${ }^{3 \tau}$ Consistent with this purpose, defendants should not be allowed to escape the threat by entering into a consent decree after extended litigation. But to admit decrees which deny violation as prima facie evidence in private actions would require a deliberate disregard of the statutory language. Moreover, the decree would offer little assistance to the private litigant, since it would not contain the evidence which he needs most - evidence as to violations of the antitrust laws. ${ }^{38}$ Consent decrees ordinarily reserve judgment as to whether the defendant has violated the antitrust laws; while a court might admit the decree, it could hardly contradict the language of the decree and regard it as evidence of guilt. Of course, if the Antitrust Division pursued a policy of pressing to a final adjudication all suits wherein consent decrees are not immediately entered, the need for resolving the conflict would disappear. But such a policy would clearly impair the effectiveness of consent procedures and result in expensive and perhaps needless litigation. If the government feels that a suit should be fully tried in order to obtain a judgment of some value to private litigants, consent to a decree may be withheld; but where settlement at any stage of litigation is desirable, it would still be useful to hold out the exemption of Section $5 .^{39}$ In view of these considerations, consent decrees lacking an

${ }^{37}$ Deluxe Theatre Corp. v. Balaban \& Katz Corp., 95 F. Supp. 983 (N.D. IIl., 1951); Homewood Theatre, Inc. v. Loew's Inc., 110 F. Supp. 398 (D. Minn., 1952).

${ }^{35}$ Any final judgment, contested or not, deriving from a criminal or equity proceeding is of limited value to a private litigant. While the plaintiff must show (1) defendant's violation, (2) causal connection between violation and injury and (3) amount of damages, a judgment will ordinarily assist only in proving the first of these elements. Since an equity decree ordinarily contains findings of fact, the issues resolved by the decree may be apparent but there is no requirement that such findings be made. United States v. Institute of Carpet Mfrs. of America, I F.R.D. 636 (S.D. N.Y., 1941). A criminal judgment usually contains only bare findings of guilt based on a general jury verdict. But in Emich Motors Corp. v. General Motors Corp., 340 U.S. 558 (1951), the Supreme Court gave additional evidentiary value to such judgments in holding that they constitute findings of coercive conduct as well as conspiracy. While the indictment cannot be read into the record, the trial judge in the private action may examine the charge to the jury in the criminal action to determine what facts were necessary to the finding of guilt. Emich Motors v. General Motors Corp., 181 F. 2d 70 (C.A. 7th, 1950).

Originally Section 5 provided for a conclusive presumption, but fearing that this would be unconstitutional, the Senate substituted a prima facie presumption. H.R. Rep. No. 627, 63d Cong. 2d Sess. 2 (1914); Sen Rep. No. 698, 63d Cong. 2d Sess. 45, 48 (1914).

Once a judgment is introduced, however, a jury may attach far more significance to it than the instructions dictate. Testimony of Jerrold G. Van Cise, Hearings before the Subcommittee on Study of Monopoly Power of the House Judiciary Committee on H.R. 7905, 81st Cong. 2d Sess. 52 (1950). See generally Clayton Act, Section 5: Aid to Treble Damage Suitors? 61 Yale L.J. 417 (1952); Antitrust Enforcement by Private Parties: Analysis of Developments in the Treble Damage Suit, 61 Yale L.J. 1010 (1952).

${ }^{39}$ Theoretically, the court also has power to reject a consent decree even though both parties agree to it. In fact, the courts spend little time examining the decrees and apparently make no independent judgment of their acceptability. Between 1935 and 1945, of 106 antitrust actions ending in consent decrees, 80 were entered within three days 
admission of violations should not be admissible whether testimony is taken or not.

As previously indicated, judgment in a criminal proceeding based on a plea of nolo contendere would come within the exemption proviso if rendered without testimony. If entered after testimony, such judgment would suffer a disability similar to that affecting consent decrees. For while a nolo contendere plea does constitute at least an implied admission of violation, judgment on the plea is not an estoppel as to any facts necessary to establish the cause of action. ${ }^{40}$ This, in fact, is the principal distinction between the nolo plea and the plea of guilty. ${ }^{41}$ Moreover, quoting from Twin Ports Oil Co. v. Pure Oil Co., "The Clayton Act does not attempt to change the effect or scope of a judgment entered on a plea of nolo contendere. Congress was presumably cognizant of the long line of decisions which hold that a plea of nolo contendere does not create an estoppel ... [T] he judgment ... can have no probative value ... in a third party suit. By the very terms of the Act, it is limited in its scope to such matters respecting which the judgment would be an estoppel." 43

Applying here the language of the Twin Ports case along with the general observations concerning the exemption for consent decrees entered after the taking of testimony, the conclusion seems warranted that judgment on a nolo contendere plea should likewise be inadmissible whether entered before or after testimony is given. Unfortunately, the one serious obstacle to this conclusion is that the language of Section 5, "entered before any testimony has been taken," is thereby rendered meaningless.

At this juncture, a relationship can be established between the admissibility issue and the question of pendency discussed earlier in this comment.

after the complaint was filed. Appendix D, H.R. Rep. Committee on Small Business, Monopoly Subcommittee, U.S. v. Economic Concentration and Monopoly Appendices (1947).

${ }^{40}$ Hudson v. United States, 272 U.S. 451 (1926); Twin Ports Oil Co. v. Pure Oil Co., 26 F. Supp. 366 (D. Minn., 1939) ; People v. Daiboch, 265 N.Y. 125, 191 N.E. 859 (1934).

${ }^{4}$ State v. Suick, 195 Wis. 175, 217 N.W. 743 (1928); People v. Edison, 100 Colo. 574, 69 P. 2d 246 (1937); State v. Burnett, 174 N.C. 796, 93 S.E. 473 (1917). In Twin Ports Oil Co. v. Pure Oil Co., 26 F. Supp. 366 (D. Minn., 1939), it was suggested that judgments based on a plea of guilty before testimony is taken are likewise within the exemption proviso. However, it can hardly be said that by pleading guilty a defendant is consenting to the judgment of the court in the same manner as one who enters a consent decree formulated by mutual agreement. Consult Dix, Decrees and Judgments under Section 5 of the Clayton Antitrust Law, 30 Geo. L.J. 331 (1942). But cf. Government Judgments as Evidence in Private Antitrust Proceedings: Section 5 of the Clayton Act, 46 Ill. L. Rev. 765, 773 (1951). If judgment is suffered by default, defendant also may come within the exemption proviso. See Cromwell v. County of Sac, 94 U.S. 351, 356 (1876).

\footnotetext{
42 26 F. Supp. 366 (D. Minn., 1939).

"Ibid., at 378 .
} 
While a government suit may be technically pending, there is no point in holding the statute of limitations in suspension if the judgment eventually rendered will not be admissible. On the other hand, if a judgment can be technically "final" and yet be inadmissible, even though further proceedings may produce an admissible judgment, there is good reason for suspending the statute of limitations applicable to private suits. In other words, the pendency of a government suit should be considered as continuing until an admissible judgment is rendered or until it becomes apparent that such a judgment cannot be obtained. This approach would be consistent with the apparent purpose of Section 5 to suspend the statute of limitations only when doing so would be valuable to private litigants.

The treble-damage claimant, even under this approach, faces the difficult problem of predicting whether a particular consent decree may later be converted into an admissible judgment. In view of the variety of provisions appearing in consent decrees, the only reliable answer to this problem would be that which a court might offer. Unfortunately, the only means by which the litigant can obtain a ruling would be intervention in the government's action, and such intervention would not be permissible under the Federal Rules of Civil Procedure. ${ }^{44}$ It is conceivable, of course, that defendants and the government might include a special provision in the consent decrees stating whether or not the action is regarded as terminated. While the parties in government actions do, as a rule, consider whether the statute of limitations for private actions will be suspended by the decree, there is seldom a special provision which explicitly determines the issue. The private litigant, even though favored by the statutory policy, must use his own judgment in deciding when to bring suit and cannot count on the courts or the government's action for assistance.

"Rule 24(a), concerning intervention as of right, provides that "when the representation of the applicant's interest by existing parties is or may be inadequate and the applicant is or may be bound by a judgment in the action" the applicant may intervene. While it might be said that the private litigant's interest would not be adequately represented unless the decree itself stated whether the government's action is terminated, it is clear that a consent decree would not bind the treble-damage suitor in the sense of res judicata intended in Rule 24(a). Consult 4 Moore, Federal Practice $\$ 24.08$ at $\mathrm{n}$. 2 (2d ed., 1950).

Permissive intervention is allowed under Rule 24(b) "when an applicant's claim or defense and the main action have a question of law or fact in common." This rule clearly would not help the private suitor since the pendency of the suit for purposes of the statute of limitations against treble-damage actions would never be a material issue in the government action.

As an alternative to intervention, the private litigant might, as a practical matter, bring his action and hope that it would not come to trial before the government took further action to obtain a contested judgment. Conceivably, the trial court might, in its discretion, grant a further stay of trial, but its determination of whether a consent decree terminated the government's action would not be binding on the court hearing the action or on the parties to the decree. Hence, the private suitor would be back where he started, still faced with determining for himself whether the government's action is still pending. 